【総説】

\title{
食品の健康表示制度と科学的 根拠に関する国際比較 International Comparison of Health Claim on Foods and the Scientific Evidence
}

\author{
清 水 俊 雄 \\ Toshio SHIMIZU
}

フレスコ・ジャパン有限会社

\begin{abstract}
【要 旨】
特定保健用食品は個別評価型の表示制度として世界最 初の制度である。栄養機能食品は規格基準型の表示制 度であり， 2 つのシステムを制度化し，実用的に運用 しているのは日本だけである.

コーデックス委員会では栄養素機能表示, その他の機 能表示, 疾病のリスク低減表示の 3 つの表示に関する 「栄養及び健康表示の使用に関するガイドライン」を 2004 年に総会で採択し, 今後の食品の世界基準となる. アメリカでは栄養表示・教育法により食品成分の疾病 のリスク低減表示ができるようになり，ダイエタリー サプリメント・健康・教育法により人体の構造と機能 に関する効果を表示できることになった. 2003 年よ り疾病のリスク低減に関する根拠の強さを格付けする 条件付きへルスクレームをスタートしている. EU は 成長, 分化, 身体の機能に影響を及ぼす表示と疾病の リスク低減表示を含む栄養・健康表示制度を EU 規則 案として発表した. 更に, 機能性食品の科学的評価と 健康表示に関する調査・研究を行うことを目的に PASSCLAIM プロジェクトを進めている．食品の健康 表示に関するハーモナイゼーションは今後益々重要と なり, 研究開発と制度作りで世界に先駆けた日本の主導 的な役割が期待される.
\end{abstract}

$$
\text { 【キーワード】 }
$$

機能性食品, 健康表示, 特定保健用食品, 保健機能食 品, 栄養機能食品, 栄養素機能表示, 構造機能表示, 疾病リスク低減表示

1. はじめに

1984 年に文部省（現文部科学省）は特定研究として, 世界に先駆けて生体調節機能を有する食品に関するプロ ジェクトを発足させ，この分野での世界のパイオニアと なった.このプロジェクトでは，食品の機能を栄養機能 (生きて行く上で必須である栄養素やカロリーを供給す る機能), 感覚機能 (味・香りなどの感覚に関わり美味し いと感じさせる機能), 体調調節機能 (生体防御, 疾病の 防止，疾病の回復，体調リズムの調整，老化抑制などの 機能）の 3 つに分類し，第 3 番目の機能を有する食品を 機能性食品と定義した. このプロジェクトを切掛けに， 食品の健康機能に関寸る研究・開発が系統的に進められ, その科学的根拠が蓄積されてきた。しかしながら食品の 体調調節機能は製品を見たり，食べたりしても，短期間 にその機能を簡単に判断することはできない. そのため, 体調調節機能を表示することは消費者と生産者の両者に とって重要である，消費者にとって，新聞やテレビによ り日々伝えられる健康情報が汇監する中で, 製品に記載 された表示は最も直接的で重要な情報源であり, 間違っ た選択をしないために必要である。また，生産者にとっ ては，短期間の摂取ではその機能を判定できない体調調 節機能を製品に表示することで他の製品と差別化するた めに表示制度が重要である.

一方, 食品の健康に関する機能を表示することは薬事 法に基ついて厳しく規制されているため, 原則として食 品の健康機能を表示することができなかった. 食品に健 康表示ができる新しい制度を検討した結果, 1991 年に個 別に審査して表示を許可する特定保健用食品が制度化さ れた. 更に，2001 年には規格基準型の栄養機能食品制度 が制定され，ビタミン，ミネラルの栄養機能を基準に基 ついて表示できるよらになった。 これらは食品に健康機 能を表示する制度の世界的な先駆けとなった.

先進国の多くは薬事法に相当する法律があり, 食品に 病気の治療や予防, 身体の構造や機能に影響を及ぼす表 示をすることは原則として禁止されているが, 食品の健 康に及ぼす効果が研究開発により明らかにされてきたこ とから, 各国で制度化の検討がなされている. 食品も国

受理日：2005 年 6 月 20 日

干107-0052 東京都港区赤坂 2-22-20-102 Tel: 03-5549-4637 Fax: 03-5549-4638 E-mail: shimizu@frescojapan.co.jp 
際化が進み, 生産から消費までをひとつの国の中で完結 することは不可能な時代である. 特に, 日本では食品の 自給率が低下しており, 食品の輸入は重要な課題である. このため, 健康機能に関する表示に関しても, 国際的 なハーモナイゼーションが必要であり，世界貿易機関 (WTO) に委託されて食品の国際基準を決定するコー デックス委員会 (Codex Alimentarius) のガイドラインは日 本の健康表示の制度に直接影響を及ぼすものである. 2004 年に, 健康表示に関寸るガイドラインが総会で採決 され, 更にその健康表示の評価法について検討が進めら れている. また，健康表示食品の市場規模が最も大きい アメリカ合衆国に拀いて, 2003 年, 疾病のリスク低減表 示に関するへルスクレームの科学的根拠を検証し，その 科学的根拠のレベル毎に表示のランク付けをするガイド ラインが施行された．EUに扐いても2003 年に食品の栄 養・健康表示の規則案が発表され，現在，加盟各国の意 見を基に，施行に向けて討議を進めている。このように 海外では科学的根拠に重点を置いて, 制度作りが前進し でり, 研究開発と制度づくりで世界に先駆けたわが国 に扒いて子 2005 年 2 月に導入された新特定保健用食品の 制度を基に，国際的整合性を考慮に入れて，科学的根拠 に根ざした制度として行くことが必要である.

\section{2. 海外の健康表示制度と科学的根拠}

\section{1 コーデックス委員会 (Codex Alimentarius)}

1995 年に設立された WTO（世界貿易機関）が食品の 国際的ガイドライン作成を FAO (食糧農業機関) とWHO （世界保健機関）に依頼したことにより，既に設立されて いたコーデックス委員会がその役割を担うことになっ た. WTO 加盟国の国内規格は特段の理由がない限り, こ こで策定された規格を基礎とすることになっている．健 康強調表示に関連する部会はカナダで開催される食品表 示規格部会とドイッで開催される栄養・特殊用途食品部 会である．原案の作成から始まり，加盟国の意見集約の 後, 最終討議・採択, 加盟国への通知まで 8 つのステッ プがある. 2003 年 5 月のオタワ会議に打いて, 栄養素機 能表示 (Nutrient Function Claim), その他の機能表示 (Other Function Claim), 疾病のリスク低減表示 (Disease Risk Reduction Claim) がコーデックス総会に提案されること になった。

栄養素機能表示とは，「身体の成長，発達，正常な機能 における栄養素の生理学的な役割の表示」を意味する表 現であり, 例兄ば「カルシウムは強い骨と歯の発達を助 ける」がある。「その他の機能強調表示」とは，「全体の 食事の中で身体の正常な機能または生物活性に関連し,
その食品成分を摂取することによる特定の有用な効果に 関与している表示であり，このような表示は，健康に関 する積極的な貢献, 機能の改善, 健康の保持に関連して いる.」と定義されている. その例として,「物質 $\mathrm{A}$ は健 康に関連する生理機能または生物的活動を改善する効果 があります。この食品は物質 $\mathrm{A}$ を $\mathrm{Xg}$ 含んでいます.」が 記載されている. 疾病のリスク低減表示とは, 「食生活に 扣いて，食品あるいはその成分の摂取と，疾病及び健康 に関する状態の進行（発症）に関するリスクの低減との 関係を示寸表示である。」であり，例えば，「栄養素 A （または食品成分 B）が多い健康的な食事は病気 D のリ スクを減らすかもしれない，この食品は栄養素 A または 物質 Bが多くなっています。」のよらな表示がある。

このガイドラインには, 健康に関する表示内容は科学 的根拠に基づくことが記載されて抒り，2004 年 7 月には ジュネーブの総会において，この提案は正式なガイドラ インとして採択された1).

2002 年 11 月のベルリンの栄養・特殊用途食品規格部 会会議に颃いて,「健康強調表示の科学的根拠」に関する 討議を進めることになり，2003 年 11 月のベルリンの同 部会会議に佂いて,「健康表示の科学的根拠」のガイドラ インが提案され, 2005 年のボン会議では更に具体的に議 論されることになっている.

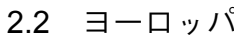

\subsection{1 ヨーロッパ連合 (European Union=EU)}

(1) 食品安全白書と関連法規

2000 年 1 月に発表された EU の食品安全白書 ${ }^{2}$ には, 「消費者は食品の品質と含有成分についての情報を知る 権利があり，それにより Informed Choice（情報を受けて 選択すること）が可能となる．食品の表示は更に前進す る必要があり, バランスの取れた食事の重要性とその健 康への効果は，消費者に知らせるべきである.」とあり， 食品の健康に関する情報を消費者に伝えるための制度の 必要性を訴えている.

更に, 2000 年 8 月にフードサプリメント (Food supplement) に関する EU 指令案 ${ }^{3)}$ が公表され,「ライフス タイルと食習慣が変化したことにより，ビタミンやミネ ラルのよらな必須栄養素の摂取が不十分になってきてい る。一方，幾つかの必須栄養素を推奨摂取量以上摄取す ることにより，健康に対する実効的または潜在的な効果 が生まれることが明らかにされてきている（中略）しか しながら，上市された製品が安全であることと，表示を 通じてその製品に関する充分で正しい情報が提示されて いることは担保されなければならない，食品は安全であ ることと表示に充分で明確な情報が提示されていること 
が EU の食品法の基本的な $2 つ の$ 原則である.」と記載さ れ，フードサプリメントの安全性と有効性汇関する表示 の科学的実証の必要性が強調されている.

指令本文中に, 13 種類のビタミンと 15 種類のミネラ ルが挙げられて扣り，個々の栄養素として使用できる 112 種の化合物も列挙されている. 安全上限使用量は, 食 品科学委員会 (Scientific Committee for Food) へ諮問を現在 行っているが，製造者・輸入販売者は一般に認められて いる科学的データーを基にして上限值を算出して, 製品 に表示しなければならないとされている.

2003 年 7 月に「栄養と健康表示に関する規則案」 ${ }^{4)}$ が 発表され，食品の健康表示には食品成分が持つ成長，分 化，身体の機能に影響を及ぼす役割に関する表示と疾病 のリスク低減に関する表示が含まれると記載されてい る. 健康表示の制度は, 既に確立し異議のない科学的根 拠に基づく健康表示（一般表示）と新しく科学的実証が 行われた健康表示（新規表示）の2つより成り立ってい る. 一般表示については, この規則の施行後 3 年以内に ポジティブリストを作成することになっている．新規表 示の許可の審査を受けるには, 申請者は欧州食品安全機 構 (European Food Safety Authority: EFSA) に(1)科学的根拠, (2)健康表示, (3)関連する科学情報を文書として提出して 審査を受けることになる，これらのリスト作成，審査に 当たっては, 後述する PASSCLAIM プロジェクトの報告 書を参考に実施すると記載されている。 この規則案には 砂糖, 脂肪, 塩について過剩摂取と生活習慣病との関係 を食品の義務表示とすることと老化防止や肉体疲労など のあいまい表示や精神・心理表示なぞの科学的実証が困 難な表示, 食欲抑制やダイエットなぞに関する表示を禁 止することが盛り込まれて打り，これらの条項を中心に 現在も議論が続いて和り,施行は 2006 年になると見られ る.

（2）機能性食品プロジェクト

EU では 1996 年に, 機能性食品の科学的調査, コンセ プト提案を目的に FUFOSE プロジェクト「The European Commission Concerted Action on Functional Foods Science in Europe」を設置し，適切なマーカーを選んで食品やその 成分の身体への機能を立証できれば，食品成分の機能の 科学的根拠が得られたことになり, 直接健康に関する表 示をすることが可能となる，との考劣をとめている5 その表示には高度機能表示と疾病のリスク低隇表示の 2 種類があり，コーデックス委員会の考方方を先取りした ものとなっている.

更に 2001 年には, PASSCLAIM (Process for the Assessment of Scientific Support for Claims on Foods) プロジェク トを設立し, 2005 年 3 月までの 4 年間, FUFOSE プロ
ジェクトの実用化に向けて機能性食品の科学的根拠に基 づく評価法の調査を行い, 健康表示の科学的根拠の評価 法とマーカーに関する提案をしている，機能性食品の制 度と評価に関する国際的な調査を踏まえて提案されたコ ンセンサスは下記の通りである.

(1)入手可能な全ての試験結果 ・情報について科学的に検 証すること.

(2)健康表示には, Generic Claim (一般的表示 : 学術文献 や国または世界の保健機関/科学専門委員会で一般に 受け入れられている事実に基づく表示）とProduct Specific Claim（個別評価の表示：食品または食品成分 毎にそれぞれの効果を科学的事実に基づいて証明する 必要がある表示）を区別して評価すること.

(3)Product Specific Claim についは，ヒト介入試験が必要 であること.

(4)マーカーの種類により高度機能表示と疾病のリスク低 減表示に分類されること.

PASSCLAIM プロジェクトは, 基準原則に関するコン センサスの作成を実施した後, 下記 7 つ健康機能に関 する評価法とマーカーに基づく健康表示を実用化するた めの共通基準をつくるワーキンググループを設置し, 調 查・討議が行われた. その結果, 2003 年 5 月に下記の (a) から (c) の報告書6)，2004 年 7 月に (d) から (g) までの報 告書 ${ }^{7)}$ が出版された。 これらの報告書は, 健康表示の評 価法とマーカーについて科学的根拠に基づいて網羅的に 調査, レビューした内容になっている, 各ワーキングルー プの結論をまとめて下記に記載する.

(a) 食事関与心血管疾患

食事が関与した LDL コレステロールと血圧の変化に 対しては高度機能表示と疾患リスクとの関係が確立して いるため科学的実証が可能であるとしている. HDL コレ ステロール，空腹時トリグリセリド，打よび血漿ホモシ スティン值は健康表示と定量的な相関が困難であり, 血 液凝固拈よび酸化傷害に関しては，健康表示と相関する マーカーの開発が必要であるとしている.

(b) 骨の健康々骨粗鬆症

骨粗鬆症については，骨中のカルシウム含量の尺度で ある骨密度 (BMD) が広い年齢層の男女の骨強度に関連 した高度機能表示のマーカーであるとしている。骨折リ スクの高い国の 50 歳以上の人では, BMD が骨折の疾病 のリスク低減表示のリスクマーカーとなるとしている.

(c) 運動能力とフィットネス

筋力, エネルギー代謝, 拱食量, 消化管機能の試験が 健康表示の根拠として信頼性打よび妥当性が概数良好で あるとしている. 
(d) 体重調節，インスリン感受性，糖尿病リスク

体重調節は体脂肪の蓄積が指標となり，体脂肪の調節 に関与する多くの機能も測定可能である. メタボリック 症候群はインスリン感受性やそれに関連する脂肪毒性, 体脂肪組成, 酸化ストレス, 炎症, および血管機能が科 学的評価マーカーの候補となる. 糖尿病のターゲットは, 血糖值の調節, 糖の利用能, およびインスリンの分必と 感受性である.

(e) 食事に関連する癌

ヒトの悪性腫瘍に打ける真のエンドポイントは表示の 根拠として測定できるものはなかったが，結腸ポリープ などの前癌病変は有効なマーカーとみなされ，現状では ヒトでのポリープ再発が疾病リスク低減表示の根拠とな りらる唯一のマーカーである.

(f) 精神状態と行動

気分，喚起 (賦活, 覚醒, 注意, 睡眠を含む), 動機づ けと努力，認知，記憶，および知性などの機能に対する 評価手法（テスト，アンケート，その他）をレビューし た結果, これらの機能改善は適切なテストで直接評価で きることが多く, 食品は脳機能に作用し, 精神状態と行 動に影響を与えている. よって, いくつか精神機能に関 係する表示を実証する有効な科学的手段がある.

(g) 腸管の健康と免疫

胃腸に関するマーカーである吸収と分必，排泄習慣と 通過時間, 腸内菌叢, 胃内容物排出と運動性などの評価 法は，個人差があるため解釈は複雑である，免疫系も定 量的に判定するのが難しく，免疫機能を明らかにできる 単一の測定法はなかったが，複数のマーカーを組み合わ せて測定することにより機能の評価が可能となる.

ポルトガルの首都リスボンで開催された 2004 年 12 月 の総括会議の討議内容を踏まえて, 2005 年 3 月までに理 事会を開催して基本コンセプトについて討議し，各ワ一 キンググループのリーダー会議で相互の整合性を確認 し，それに基づき各グループで集約を行い，最終の総括 報告書を作成することになっている，総括報告書を作成 し, EC 本部に提出後, 総括報告書の出版は 2005 年 7 月 以降となると予想される.

\section{2 .2 英国の状況}

食品の健康表示に関する実施規則を確立することを目 的に，1997 年に消費者団体，行政当局，産業界からなる プロジェクトが設立された。 その報告書 ${ }^{8)}$ に Generic Health Claims (一般健康表示) 及び Innovative Health Claims （新規健康表示）の 2 つの表示を提案している. 一般健康 表示は既に一般的に認知されている知識に基づく表示で ある. 専門委員会により表示例が示され，個々の商品で の検証は不要である．新規健康表示は一般健康表示以外
の表示であって, 個別に科学的根拠の実証が必要である. 科学的根拠は単なる実験結果だけではなく, 文献の調査・ 評価を含めた「事実の統合性」(Totality of Evidence) と適 切なヒト試験に基づく有効性の実証が必要である。これ は，PASSCLAIM のコンセンサスの基礎となった考え方 であり，日本の保健機能食品制度およびューデックス食 品表示規格部会の原案と同一の考えとなっている。

\subsection{3 スウェーデンの状況}

ヨーロッパに打いて，健康表示が業界自主基準として 最初に制度化された国である. 1990 年に食品業界自主基 準として公開，実施され，1996 年に修正後，翌年より適 用されている9).

表示は下記の表示例の通り，食事と健康に関する部分 と製品の成分に関する部分の 2 つりなる. 表示内容は, 肥満，血中コレステロール，血圧，動脈硬化，便秘，骨 粗鬆症，ら蝕，鉄欠乏が提示されて扣り，具体例は次の 通りである.

表示例:「飽和脂肪酸は血中コレステロールレベルを上昇 させます。

この商品は飽和脂肪酸の含有量が少なくなって います.」

上記の健康表示は，コーデックス食品表示規格部会に抒 いて，2 Step Principle と呼ばれ，具体的な表示例として 提案され，国際的な評価を受けている. 今後の国際的な 表示のハーモナイゼーションを図る上で重要な意味を持 つと考えられている.

個別審査型 (Product-Specific Physiological Claims) が 2001 年に自主基準 ${ }^{10)}$ として, 独立の評価機関が通常の食 品形態を対象に審査をする制度が設置された。審査の概 要は下記の通りである。（1）有効性の評価にはヒト試験 が必要であること.（2）安全性の評価は EU とスウェー デンの食品に関する規則に準拠していること。（3）国際 的専門家又は国際的雑誌に执いて，科学的根拠があると の評価を受けていることが必要であることとなってい る.

スウェーデンの制度は規格基準型と個別審査型の 2 本 立てとなって扣り，制度の枠組みは日本の特定保健用食 品と栄養機能食品の制度と類似するところが多い. 今後, ヨーロッパが FUFOSE と PASSCLAIMのコンセンサスに 則って法制化を進めることで，日本で構築された考え方 がグローバル・スタンダードとなることが期待される。

\section{3 アメリカ (US)}

\subsection{1 栄養表示・教育法 (NLEA)}

1990 年に施行された栄養表示・教育法 (NLEA) により, 連邦食品医薬局 (FDA) が疾病または健康状態の指標との 
関係が科学的に立証されていると認めた食品成分と疾病 のリスク低減との関係に関する表示（狭義のへルスク レーム）を定め，基準を満たしている食品に表示できる 制度が設立された。 アメリカのへルスクレームは, 食品 成分と疾病との関係関する表示で，コーデックスで定 義される「疾病のリスク低減表示」とほ泳類似の表示内 容であり, 身体の構造と機能に影響を及ぼす表示(構造・ 機能表示）を含むコーデックスで定められた健康表示と は異なる。本文でもアメリカのへルスクレームは疾病の リスク低減表示の意味で用いる。

\subsection{2 ダイェタリーサプリメント健康・教育法 (DSHEA)}

1994 年に制定されたダイエタリーサプリメント健康・ 教育法 (DSHEA) により，ビタミン，ミネラル，ハーブ, アミノ酸等について, 企業が科学的根拠を実証したと FDA 几届出するだけで, FDA はその科学的実証を審査す ることなく，身体の構造と機能に関する効果を表示でき ることになった，この法律に基づいて，多くのダイエタ リーサプリメントが販売され，2 兆円を超光る市場が形 成された．しかしこの法律には，少なくとも3つの重大 な問題点がある。 まず第 1 亿, 有用性と安全性に及活す 食品の科学的根拠をどのように実証するかの方法論が明 記されていないことである。例えば，ヒトでの試験が義 務づけられていないため, 動物試験の結果だけで効果が 表示されている可能性がある. 第 2 の問題点は, 第 3 者 の評価がされないことである. 試験の条件, 実施の方法, 結果の解析, 結論の導き方まで開発企業だけの考兄で有 効性と安全性の試験が行なわれ, FDA の評価が行われな い. 第 3 の問題点は, 科学的根拠を実証した報告書の公 表が義務づけられていないことである，社内試験で有効 性を確認したと企業が考えれば，その内容を公表しなく ても良いことになり，消費者に知る権利が保証されてい ないことになる。

FDA は上記の問題を解決するため, 2002 年にダイエタ リーサプリメントによる健康被害も考慮して, 有効性と 安全性に関する指針を制定することを宣言 ${ }^{11)}$ 乙, 2004 年 11 月にダイエタリーサプリメントについて, 構造・機能 表示の科学的実証汇関する指針案を発表した，従来，身 体の構造と機能に影響を及ぼす表示の評価については基 準がなく，評価法は企業の自主基準に任されていたが， 今後七ト試験で実証されていなければ規制の対象とする ことが記載されて和り, 今後ダイエタリーサプリメント に記載されている表示の七ト試験での科学的実証が進む と考光られる.

2.3.3 条件付きヘルスクレーム

FDA が NLEA に基づいてへルスクレームを審査する
基準が不明確であることと基準を満たしていない表示を 否認することは憲法の言論の自由に違反しているとの理 由で, 1999 年にピアソン・シャララ訴訟で FDA が敗訴 した，そのため，FDA は基準の定義に関する産業界向け 指針 ${ }^{12)}$ を発表し，更に基準を満たしていない場合の表示 として, 条件付きへルスクレーム (Qualified Health Claim) の制度を導入することとした．有効性の科学的実証が十 分でなくても，そのことを適切な表現で消費者に伝え， 判断は消費者自身に委社る制度である。この制度では従 来から対象であった通常の食品の形態だけでなく, ダイ エタリーサプリメントについても評価することとし，有 効性の科学的根拠を評価してその根拠のレベルをランク 付けするシステム ${ }^{13)}$ として公表し, 2003 年 7 月に指針を 発表した ${ }^{14)}$.

条件付ヘルスクレームは, 消費者の健康と安全性に脅 威を与えないことが大前提であり，表示を裏付けるデー タが否定するデータよりも質・量ともに上回っていれば, ヘルスクレームが可能であるが，適切な条件文または否 認文をつける必要がある，消費者にできるだけ正確に科 学的根拠に関する情報を伝兄，購入の判断は消費者自身 に委ねることとした。

科学的根拠に基づく序列システムの手順として, まず, 無作為二重盲検比較試験, コホート研究, 症例対照研究 なぞの試験の方法を順位付けし，次にバイアスがぞれだ け低減されているかの程度を科学的証拠の質として評価 し, 最後に被験者数, 実施設備の数, 実施試験の数など の量的評価に加光，従来の知見との整合性などを科学的 根拠の強度として評価する。そその結果下記のように，表 示のランク $\mathrm{A}$ は条件をつけないールスクレームとし, ラ ンク $\mathrm{B}$ から $\mathrm{D}$ は条件付きのへルスクレームとするとし た.

A. 高 (High) : 明確な科学的根拠に基づいている。へル スクレームに明確な科学的根拠があるもので，条件付 けは必要でない。

B. 中 (Moderate)：良好な根拠はあるが完全には確定さ れてない。

C. 低 (Low)：根拠はあるが限られたもので確定されて いない.

D. 最低 (Extremely Low)：ヘルスクレームを支持する科 学的根拠は殆どない.

FDA はすべての条件付きへルスクレームを，表示され る前に評価することになり，この過程で入手可能な科学 的根拠についての総合的評価と, 必要に応じて FDA 以外 の専門家スタッフによる詳細な評価が行われるものとさ れている。またFDA はこれらの一連の活動において, 主 要な消費者保護担当の部局である連邦貿易委員会と密 
接な連携をもって行らことになっている.アメリカでも, 条件付きへルスクレームの指針と構造機能表示の科学的 実証の指針と合わせて，実施することで，科学的根拠を 評価して健康表示を行らグローバルスタンダードの方向 性に近づいて行くと考兄られる。

\section{3. 日本の健康表示と科学的根拠}

2001 年 4 月に, 既存の特定保健用食品と新規の栄養機 能食品とからなる保健機能食品の制度が創設された。個 別評価型の特定保健用食品に対して, 栄養機能食品は栄 養成分の機能について一定の規格基準を満たせば個々に 許可を得ずに定められた表示ができる制度である。保健 機能食品の設立の目的は, 消費者に食品の健康に関する 情報を十分に伝え, 消費者自らが自分に適した食品を選 択するために，食品の機能表示を拡大寸ることにある. この制度の定着により，いわゆる健康食品の虚偽・過大 な表示や広告を排除することができると考兄られる。

\section{1 特定保健用食品}

\section{1 .1 審査制度}

特定保健用食品は申請された個々の製品毎に有効性と 安全性の科学的根拠を評価して，表示を許可する制度で ある. 申請に必要なデータは大きく分類すると 3 つのカ テゴリーに分けることができる．第一にヒト試験を実施 して機能に関して有效性の科学的根拠を明らかにしてい ること, 第二に食経験も踏まえてヒトでの安全性が確認 されていること，第三に機能成分の定量的な把握ができ ていることである.

審査は厚生労働省と食品安全委員会により選ばれた専 門家による評価に基づいて行われる。 まず，厚生労働省 の新開発食品評価調査会で有効性の評価が行われ，次に 食品安全委員会の新開発食品専門調査会により「適切に 摂取すれば，安全性上問題がない」との評価を受けた後 に, 更に, 厚生労働省の新開発食品調査部会での総合的 評価が行われ，最後に薬事・食品衛生審議会で審議され る. 有效性と安全性の科学的根拠が了承された後に, 指 定された研究機関による関与する成分の分析法の評価と サンプルの分析を行い, 特定保健用食品として許可され る.

\section{1 .2 新しい特定保健用食品制度}

厚労省は 2002 年より健康食品の制度のあり方の検討 を行い,「「健康食品」に係る今後の制度のあり方につい て (提言)」を 2004 年 11 月に発表し, パブリックコメン 卜を踏まえて一部修正されて，12 月末に実施内容が公表 された。その主な部分は特定保健用食品の制度の中に下
記の条件付き特定保健用食品，規格基準型特定保健用食 品，疾病のリスク低減特定保健用食品を新たに設けるこ とであり，2005 年 2 月 1 日渻令改正が行われた ${ }^{15)}$.

（1）条件付き特定保健用食品

既存の特定保健用食品の審査で要求している有効性の 科学的根拠のレベルには届かないが，一定の有効性が確 認される食品を条件付きで特定保健用食品として許可す るものであり，下記の要件を満たす場合に，「根拠は必ず しも確立されていませんが， $\triangle \triangle$ 亿適している可能性が ある食品です.」の条件文をいれた表示が許可される.

(1)無作為化比較試験の有意水準 $10 \%$ 以下

従来特定保健用食品の試験結果には危険率 5\%以下の 有意差が求められていたが，5\%から 10\%までの有意差 で，条件付特定保健用食品として認められる。

(2)非無作為化比較試験

非無作為化比較試験で危険率 5\%以下の有意差であれ ば条件付き特定保健用食品として認められる。例えば, 過去に実施した試験に打ける対照群の試験結果を用いる ことが想定される。

(3)作用機序が不明確

作用機序に関する試験を適切に実施した後に，作用機 序が明確にならなかった場合であっても条件付き特定保 健用食品として認める.

（2）規格基準型特定保健用食品

特定保健用食品としての許可実績が十分であり，科学 的根拠が蓄積されて，事務局審査が可能な食品について 下記の基準を定め, 審議会の個別審査なく許可する.

判断基準：(1)保健の用途ごとに分類したグループにおけ

る許可件数が 100 件を超えている.

(2)関与成分の最初の許可から 6 年を経過して いる.

(3)複数の企業が当該保健の用途を持つ当該関 与成分について許可を取得している。

これら全てを満たしている関与成分は，保健の用途と して「おなかの調子を整える」旨の表示をする以下の 9 成分である.

難消化性デキストリン・ポリデキストロース・グァー ガム分解物・大豆オリゴ糖・フラクトオリゴ糖・乳果才 リゴ糖・ガラクトオリゴ糖・キシロオリゴ糖・イソマル トオリゴ糖

食物繊維，オリゴ糖ごとのグループに分け，既許可の 食品形態と同じである必要があるとされ，6 月に規格基 準に関する通知が出された。

（3）疾病リスク低減表示

関与成分の疾病リスク低減効果が国内外に打いて医学 的・栄養学的に確立されている場合，特定保健用食品の 
許可において表示を認められることになった. 現時点に おいて許可対象として認める候補としては,「カルシウム と骨粗鬆症」・葉酸と神経管閉鎖障害」の 2 つであり, 表示の内容は下記の通りである.

カルシウム：「この食品はカルシウムを豊富に含みま す. 日頃の運動と, 適切な量のカルシウムを含む健康的 な食事は若い女性が健全な骨の健康を維持し, 歳をとっ てからの骨粗鬆症になるリスクを低減するかもしれませ ん.」

葉酸 :「この食品は葉酸を豊富に含みます。適切な量の 葉酸を含む健康的な食事は，女性にとって，二分脊椎な ぞの神経管閉鎖障害を持つ子どもが生まれるリスクを低 減するかもしれません.」

これら 2 つ以外の表示として許可されるには原則とし て，複数の研究論文からなるメタアナリシスの論文があ り, 日本人の疾病の罹患状況に照らして必要性があるこ とが求められ，十分な科学的根拠を揃えた申請があった 場合に，専門家による検討が行われるとされている.

\section{2 栄養機能食品}

日本で設定された栄養機能食品制度は，ビタミン・ミ ネラルを中心とする栄養素を対象とした点で，コーデッ クスおよびEUの FUFOSE プロジェクトに拈栄養素 機能表示と同等の制度である. 栄養機能食品の機能表示 はコーデックスの栄養素機能表示例など, 国際的に定着 しているもの, 広く学会等で認められているものであっ て，国民が容易に理解できるものを機能表示にすること となった. 対象とする栄養素として 12 種類のビタミンと
5 種類のミネラルの基準が設定されている.

\section{4. 国際比較と今後の展望}

日本の特定保健用食品と栄養機能食品の制度は，世界 に先駆けたものである。日本と海外の制度を表 1 にまと めた. 健康表示には，栄養素機能表示，構造機能表示， リスク低減表示の 3 つがあり，規制する制度としては， 規格基準を定め，基準に合致していれば，定められた表 示の出来る規格基準型，個別に審査をして表示を許可す る個別審査型，単に表示の内容を通知するだけでよい届 出型の 3 つが考えられる. 日本の栄養機能食品は，栄養 素機能表示についての規格基準型の制度であり，EU の 規則案（一般表示）やスウェーデンの自主基準（1997） に類似の制度となっている．日本の特定保健用食品は構 造機能表示を製品毎に評価して許可する個別審査型であ り，EUの規則案（新規表示）やスウェーデンの自主基準 (2002)，中国の保健機能食品がこれに近い制度と考えら れる.アメリカは構造機能表示を届出型の制度としてお り，国際的に例外的な制度となっている。

2005 年 2 月に通知された新特定保健用食品の制度によ り, 特定保健用食品の中に 2004 年にコーデックス委員会 で採択されたリスク低減表示が盛り込まれた，更に科学 的根拠のレベルを評価して条件文を付けることで，表示 を許可する条件付き特定保健用食品が追加され，アメリ カの条件付きへルスクレームの考方を取り入れてい る.ヨーロッパでは，日本の制度も参考にして新しい制 度を検討して扣り，現在，EUで施行に向け討議されて

表 1 国際的整合性に基づく日本の制度の位置付け

\begin{tabular}{|c|c|c|c|}
\hline & 規格基準型 & 個別審査型 & 海外 \\
\hline 栄養素機能表示 & 栄養機能食品 & & $\begin{array}{l}\text { Codex2004 } \\
\text { EU-FUFOSE }\end{array}$ \\
\hline 高度機能表示 & $\begin{array}{l}\text { 規格基準型特定保健用食品 } \\
\text { (2005) }\end{array}$ & 特定保健用食品（1991） & $\begin{array}{l}\text { Codex2004 } \\
\text { EU-FUFOSE } \\
\text { US-DSHEA }\end{array}$ \\
\hline 疾病リスク低減表示 & $\begin{array}{l}\text { 特定保健用食品 2005（カルシ } \\
\text { ウムと葉酸） }\end{array}$ & $\begin{array}{l}\text { 特定保健用食品 } 2005 \\
\text { (カルシウムと葉酸以外) }\end{array}$ & $\begin{array}{l}\text { Codex } 2004 \\
\text { EU-FUFOSE } \\
\text { US-NLEA }\end{array}$ \\
\hline 海外 & $\begin{array}{l}\text { UK-Code } \\
\text { EU-規則案 } 2003 \\
\text { SE1997 }\end{array}$ & $\begin{array}{l}\text { UK-Code } \\
\text { EU-規則案 } 2003 \\
\text { SE2002 }\end{array}$ & \\
\hline
\end{tabular}

Codex1997：コーデックス 1997 年指針, Codex1999：コーデックス 1999 年提案

EU-FUFOSE : 欧州連合の FUFOSE プロジェクト提案 1998 年

EU-規則案 : 欧州連合の食品の栄養・健康表示規則案 2003 年

US-NLEA : 米国の栄養表示教育法 1990 年

US-DSHEA : 米国のダイエタリーサプリメント健康教育法 1994 年

UK-CODE : 英国の自主規則 2000 年

SE1997：スウェーデンの自主規則 1997 年, SE2002：スウェーデンの自主規則 2002 年 
いる食品の栄養・健康の表示規則案の方向も日本の制度 の枠組みは合致すると考えられる，従来のアメリカの制 度にはヒトでの実証の必要性が明確になっていないこと と，効果を実証した試験結果の公表が義務づけられてい ないなど重大な問題があったが，前述したよらに，ヒト での実証が義務付けられる方向であり，今後は日本の保 健機能食品の制度が国際的に基本的考光としてハーモナ イズされてゆくと期待される.

食品の健康表示は科学的根拠に基づいて実証されたも のでなくてならない，それにより初めて，消費者に食品 の健康に関する正しい情報を提供し，その情報を用いて 消費者自らが食品を選択することにより，自らの健康の 維持と促進に役立てることができるのである．健康表示 の科学的根拠に基づく実証方法については，コーデック スでの健康表示の評価指針の作成，EU の栄養・健康表示 規則の施行に合わせて，アメリカのダイエタリーサプリ メントの健康表示の評価システムの指針作り等が前進す ると，グローバルスタンダードが一挙に進展することが 予想される。

食品の機能に関しては，その定義づけ，研究開発，表 示制度について世界に先駆けて来た日本が，国民の健康 維持・増進の根幹に関わる国際的制度化の最終段階で後 れを取ることのないようにすべきである.そのためには， 特定保健用食品に打いては審査の迅速化と透明性向上, 有効性・安全性の実証法の一層の明確化, 栄養機能食品 については基準化された成分の拡大を行い，行政，業界， 学界が協力して消費者の啓蒙と情報公開に務めることが 望まれる.

\section{参 考 文 献}

1) $\mathrm{ftp} / / / \mathrm{ftp}$. fao.org/codex/reports/al04_41e.pdf

2) White Paper on Food Safety. Commission of The European Communities, Com. (1999) 719 final, Brussels, 12, Jan. 2000.

3) EU Directive COM (2000) 222.

4) Proposal for a Regulation of the European Parliament and of the Council on nutrition and health claims made on foods, $\operatorname{COM}$ (2003) 424 final, 2003/0165 (COD).

5) Scientific Concepts of Functional Food Science in Europe. Consensus Document. Brit. J. Nutrition, 81 (Suppl. 1), 1999.

6) PASSCLAIM Phase One. Prepareing the Way, European Journal of Nutrition, 42, Supple1, March 2003.

7) PASSCLAIM Phase Two: Moving Forward. European Journal of Nutrition 43 Supple 2. June 2004

8) Code of Practice on Health Claims on Foods. Joint Health Claim Initiative. 1998.

9) Health Claims in the Labeling and Marketing of Food Products (Revised programme Aug. 28, 1996). The Swedish Nutrition Foundation.

10) Asp NG and Trossing M. The Swedish code on health-related claims in action-extended to product-specific physiological claims. Scan. J. Nutr. 2001; 45: 189-192.

11) "FDA proposes Labeling and manufacturing standards for all dietary supplements". Proposed Rule Federal Register March 13, 2003 (Vol. 68, Number 49).

12) Guidance for Industry. "Significant Scientific Agreement in the Review of Health Claims for Conventional Foods and Dietary Supplements". FDA News December 22, 1999.

13) Guidance for Industry. "Qualified Health Claims in the Labeling of Conventional Foods and Dietary Supplements". Federal Register. December 13, 2002 (Vol. 67, Number 245).

14) FDA News. P03-54. July 10. 2003.

15)「健康食品」に係かる制度の見直しについて．厚生労働省医 薬食品局長通知．薬食発第0201001号．2005.2.1. 


\begin{abstract}
International Comparison of Health Claim on Foods and the Scientific Evidence

Toshio SHIMIZU

Fresco Japan Co. Ltd.

The Japanese regulatory system of "Foods for Specified Health Use (FOSHU)" was set up to approve the statements made on food labels concerning the effect of the food on the human body in 1991 and that of "Foods with Nutrient Function Claims (FNFC)" standardized the nutrient function claims of vitamins and minerals in 2001. The International guideline of the Nutrient Function Claim, the Other Functional Claim and the Disease Risk Reduction Claims were adopted by the Codex Committee in 2004. The Structure/Function Claim, which is similar to the Other Function Claim, was enacted by the Dietary Supplement Health and Education Act in the U.S in 1994. Most of the statements of the Japanese FOSHU are close to the category of Structure/Function Claims in the U.S. or the Other function claim in Codex. The health claim on foods should always be based on scientific evidence and be in harmony with international standards.
\end{abstract}

Key words: functional foods, health claim, FOSHU, Food with Health Claim, Food with Nutrient Function Claim, nutrient function claim, structure/function claim, disease risk reduction claim 